\title{
VENTRICULAR REVERSE REMODELING AFTER SURGICAL CLOSURE IN ATRIAL SEPTAL DEFECT
}

\author{
Cicy Bastian', Jayaram Vasu², Devarajan Karimpanmavil Ayyappan³, N. Sudhayakumar 4
}

${ }^{1}$ Associate Professor, Department of Cardiology, Government T. D. Medical College, Alappuzha, Kerala. ${ }^{2}$ Assistant Professor, Department of Cardiology, Government T. D. Medical College, Alappuzha, Kerala. ${ }^{3}$ Consultant Cardiologist, St. Gregorios Cardiovascular Centre, Parumala, Pathanamthitta, Kerala. ${ }^{4}$ Professor and HOD, Department of Cardiology, Travancore Medical College, Kollam, Kerala.

\section{ABSTRACT}

\section{BACKGROUND}

Isolated ASD is the second most common form of congenital heart disease presenting in childhood. There is increase in Right Ventricular (RV) diastolic and RA dimensions due to volume overload. Adults with haemodynamically significant ASD have subnormal LV diastolic dimension. The medium and long-term followup of patients with ASD closure show excellent results. Studies have shown haemodynamic and functional improvement in RV and LV function after surgical closure of ASD. Even though the long-term remodelling changes after surgical closure of ASD is well understood, the short-term remodelling and haemodynamic changes are not well documented.

The present study is aimed at documenting short-term remodelling and haemodynamic changes after surgical closure of ASD.

\section{MATERIALS AND METHODS}

Data collected from 70 consecutive patients admitted for surgical closure of Atrial Septal Defect (ASD). Patients were divided into two groups- Group I $\leq 12$ years of age and Group II > 12 years of age. The post-operative course of patients in the hospital were observed and clinical and echocardiographic evaluation were done on the day of discharge from the hospital. Then at a threemonth followup visit, detailed clinical, ECG, radiologic and echo evaluation were done. Data obtained were coded and entered into Microsoft Excel spreadsheet and analysed using Statistical Package for Social Sciences (SPSS) version 16 for Windows. Description of sociodemographic characteristics, clinical features and echocardiographic features were done in terms of frequencies and percentages. Continuous parameters were represented by mean SD. Association of study outcome with other factors were found out by using chi-square test. Fisher exact test was used instead of chi-square test when expected frequencies were considerably small. A P value of $<0.05$ was considered to be a statistically significant result.

\section{RESULTS}

Most of the patients in the study population had elevated pre-operative RV dimensions. During post-operative period of ASD closure, the RV size decreased dramatically and RV wall motion became normal; another striking change is noticed in association with Tricuspid Annular Motion (TAM). There was a significant reduction in RVSP in both groups. There was a significant increase in LVIDd in both the groups after ASD closure.

\section{CONCLUSION}

Echocardiographic evaluation at discharge and at 3 months revealed significant reduction in diastolic dimensions of right ventricle. There was significant increase in transmitral (mitral E) flow velocity. The tricuspid annular motion showed significant reduction in both groups following ASD closure, probably due to reduction in right ventricular volume overload.

\section{KEYWORDS}

ASD (Atrial Septal Defect), RV Dimension, TAM (Tricuspid Annular Motion).

HOW TO CITE THIS ARTICLE: Bastian C, Vasu J, Ayyappan DK, et al. Ventricular reverse remodeling after surgical closure in atrial septal defect. J. Evolution Med. Dent. Sci. 2017;6(46):3571-3575, DOI: 10.14260/Jemds/2017/770

\section{BACKGROUND}

Atrial Septal Defect (ASD) is defined as any opening in interatrial septum other than a competent foramen ovale. Isolated ASD is the second most common form of congenital heart disease presenting in childhood. They account for about $10 \%$ of all congenital heart lesions. Even though many

Financial or Other, Competing Interest: None.

Submission 19-04-2017, Peer Review 27-05-2017,

Acceptance 01-06-2017, Published 08-06-2017.

Corresponding Author:

Dr. Cicy Bastian,

Associate Professor,

Department of Cardiology,

Government T. D. Medical College,

Alappuzha-688005, Kerala

E-mail: cicybastian@hotmail.com

DOI: $10.14260 /$ jemds $/ 2017 / 770$

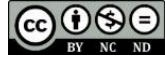
patients with unrepaired defects remain asymptomatic, the average life expectancy is 39 - 45 years.

They are classified according to the site of occurrence in interatrial septum. Secundum ASD occurs at the region of fossa ovalis. Sinus venosus ASDs occur at the junction of SVC or IVC to Right Atrium (RA) and any defect in septum primum region is designated as ostium primum defect. Coronary sinus septal defect (rare) arise from an opening of its wall with the left atrium. The most common type of ASD is the ostium secundum type. They are most prevalent in females. ${ }^{1}$

\section{Haemodynamics}

There is increase in Right Ventricular (RV) diastolic and RA dimensions due to volume overload. The interventricular septum is displaced posteriorly and leftward in larger ASDs with systolic anterior motion. As pulmonary hypertension progresses, RV hypokinesia and decreased RV Ejection 
Fraction (RVEF) develops. Tricuspid regurgitation due to RV failure also can occur.

Adults with haemodynamically significant ASD have subnormal LV diastolic dimension. The LV ejection fraction and stroke volume do not increase in these patients during exercise, even though resting Left Ventricular Ejection Fraction (LVEF) is within normal limits. Mitral incompetence is reported in $2.5 \%$ to $10 \%$ of adults with large ASDs due to mitral valve prolapse. ${ }^{2}$

The RV is adapted to the increased preload and ejects the increased preload into a low restrictive pulmonary vascular bed. The RA, RV and PA get dilated due to increased volume of blood. The interventricular septum bulges into LV reducing its size and changing its shape from ovoid to crescentic.

\section{Natural History}

Small ASD $(<5 \mathrm{~mm}$ ) closes during early childhood. Large defects $(\mathrm{QP} / \mathrm{QS}>2: 1)$ may cause Congestive Heart Failure (CHF) and failure to thrive in infancy. ASDs with significant Left to Right shunt (QP? QS > 1.5:1 may cause symptoms during adolescence or adulthood. Some patients develop significant Pulmonary Arterial Hypertension (PAH). Life expectancy is reduced in patients with large ASD. ${ }^{3}$

\section{ASD Closure - Historical Notes}

The first clinical trial for closure of ASD was done by Murray in a child by external suturing in Toronto in 1948. Lewis and Taufic reported the first successful open repair of an ASD in 1953. First transcatheter ASD closure was done by Mills and King in 1976. After this, device closure is becoming more popular and several modifications of these devices have taken place.

\section{Indications for Closure}

ASD with left to right shunt with a pulmonary to systemic blood flow ratio $(\mathrm{QP} / \mathrm{QS}) \geq 1.5$ : 1 is generally considered as and indication for closure. But even smaller shunts also should be closed because of the risk of paradoxical embolism and cerebrovascular accident. High Pulmonary Vascular Resistance (PVR) $\geq 10$ wood units is a contraindication for ASD closure. ${ }^{1}$

Closure of ASD is usually done by 1 . Surgical closure and 2. Device closure. Even though device closure has many advantages, the higher cost of treatment and risk of embolisation in large defects, especially with inadequate rims prompt the patient to opt for surgical closure. The medium and long-term followup of patients with ASD closure show excellent results. Studies have shown haemodynamic and functional improvement in RV and LV function after surgical closure of ASD. 4

\section{Timing of Surgery}

Since patients with ASD are mostly asymptomatic, closure of ASD is recommended around 3 - 5 years of age (before the child goes to school). Postponing surgery to this age also allows for spontaneous closure of ASD in some children. For infants with CHF not responding to medical therapy, surgery is done during that period. Delaying surgery to the teenage years or beyond may be harmful as shown by Murphy et al. ${ }^{5}$

\section{Haemodynamic Results}

Important haemodynamic changes occur immediately after closure of an uncomplicated ASD. Mean pressure and mean aortic blood flow in the ascending aorta increases. There is an immediate reduction in pulmonary blood flow. Right atrial pressure decreases and LA pressure increases.

RV diastolic dimensions are strikingly increased after operation, but are still above normal in many patients. Shortterm followup showed that LVEF and LVIDd, which were subnormal preoperatively increased to normal postoperatively. It is also found that RV Myocardial Performance Index (RVMPI), LV Myocardial Performance Index (LVMPI) and LA volume index also increase after closure of ASD. LV diastolic dimensions when abnormally small preoperatively increase to normal within 6 months of operation. The abnormalities of LV geometry, which present preoperatively are also corrected by repair of ASD. ${ }^{6}$

Even though the long-term remodelling changes after surgical closure of ASD is well understood, the short-term remodelling and haemodynamic changes are not well documented. It is unknown how the various chambers react to the sudden closure of the ASD. The radiological changes of remodeling (cardiothoracic ratio, main and branch pulmonary artery diameter, post-surgical electrocardiographic changes are not clear. Echo cardio-graphic parameters of changes and flow velocities are not well documented. The echocardiographic haemodynamic changes, especially the transvalvular flow velocities and RV wall motion are not clear. ${ }^{7}$

The present study is aimed at documenting short-term remodelling and haemodynamic changes after surgical closure of ASD.

\section{Aim of the Study}

To study the short-term remodelling changes after surgical closure of atrial septal defect by clinical, electrocardiographic, radiologic and echocardiographic methods.

\section{MATERIALS AND METHODS}

We have done this as a prospective observational study by collecting data from 70 consecutive patients admitted for surgical closure of Atrial Septal Defect (ASD).

\section{Inclusion Criteria}

All patients with ASD undergoing surgical closure.

\section{Exclusion Criteria}

Cases of ASD with associated cardiac defects like mitral stenosis, any other heart diseases that may modify the postoperative physiology of the patient like coronary artery disease, severe systemic hypertension, etc. were excluded.

\section{Study Design}

This was done as a prospective observational study.

Baseline data were obtained preoperatively. Along with detailed clinical examination, ECG, radiological examination of chest and echocardiography were done.

During clinical examination, the symptoms and physical findings and NYHA class were noted. 


\section{Followup}

The post-operative course of patients in the hospital were observed and a clinical and echocardiographic evaluation were done on the day of discharge from the hospital.

Then at a three-month followup visit a detailed clinical, ECG, radiologic and echo evaluation were done.

Data obtained were coded and entered into Microsoft Excel spreadsheet and analysed using Statistical Package for Social Sciences (SPSS) version 16 for Windows.

Description of sociodemographic characteristics, clinical features and echocardiographic findings were done in terms of frequencies and percentages. Continuous parameters were represented by mean SD. Association of study outcome with other factors were found out by using chi-square test. And Fisher exact test was used instead of chi-square test when expected frequencies were considerably small. A P value of < 0.05 was considered to be a statistically significant result.

Differences between patients are assessed by unpaired ' $\mathrm{t}$ ' test and frequency of parameters by the chi-square test. Linear regression analysis is used and correlation coefficients are calculated by Pearson's method.

\section{RESULTS}

\section{Baseline Data}

A total no. of 70 patients were studied. Patients were grouped according to age; 30 patients were below 12 years (average age 6.5 yrs.) (Group I) and 40 patients were above 12 yrs. with an average age of 27 years (Group II). The male-tofemale ratio in Group I was 1: 2.7 and 1: 1.1 in Group II.

The baseline radiologic and electrocardiographic features of both groups are compared in Table 1.

\begin{tabular}{|c|c|c|}
\hline & $\begin{array}{c}\text { Group I } \\
\text { (<12 yrs.) } \\
\mathbf{N}=\mathbf{3 0}\end{array}$ & $\begin{array}{c}\text { Group II } \\
(>12 \text { yrs.) } N=40\end{array}$ \\
\hline \multicolumn{3}{|l|}{ Radiological } \\
\hline CT ratio (\%) & $53.8 \pm 8.42$ & $57 \pm 10.4$ \\
\hline MPA diameter $(\mathrm{cms})$ & $3.8 \pm 1.16$ & $4.5 \pm 1.2$ \\
\hline RPA diameter $(\mathrm{cms})$ & $1.3 \pm 0.64$ & $1.83 \pm 1.12$ \\
\hline \multicolumn{3}{|l|}{ ECG } \\
\hline Sinus rhythm (no.) & $30(100 \%)$ & $39(98 \%)$ \\
\hline RAE (no.) & 8 & 14 \\
\hline $\begin{array}{c}\text { Mean QRS } \\
\text { Axis (degrees) }\end{array}$ & $+66 \pm 18.8$ & $+88 \pm 14.6$ \\
\hline rsR pattern & $25(83 \%)$ & $36(90 \%)$ \\
\hline $\mathrm{R}^{\prime}$ height (mv) & $0.9 \pm 0.7$ & $0.57 \pm 0.34$ \\
\hline
\end{tabular}

Baseline echocardiographic findings.

The baseline echocardiographic data are presented in Table 2 .

\begin{tabular}{|c|c|c|}
\hline & $\begin{array}{c}\text { Group I } \\
\text { (<12 yrs.) } \\
\mathrm{N}=\mathbf{3 0}\end{array}$ & $\begin{array}{c}\text { Group II } \\
\text { (> 12 yrs.) } \\
\text { N }=40\end{array}$ \\
\hline LVID (d) cms & $2.93 \pm 0.82$ & $3.46 \pm 1.06$ \\
\hline RVID (d) cms & $3.78 \pm 0.92$ & $4.52 \pm 1.68$ \\
\hline LA size $(\mathrm{cms})$ & $2.6 \pm 0.54$ & $2.9 \pm 0.8$ \\
\hline \multicolumn{3}{|l|}{ IVS motion } \\
\hline Flat no. (\%) & $7(23 \%)$ & $5(12.5 \%)$ \\
\hline Paradoxical no. (\%) & $23(77 \%)$ & $35(85.5 \%)$ \\
\hline \multicolumn{3}{|l|}{ ASD size } \\
\hline$<15$ mms no. $(\%)$ & $9(30 \%)$ & $13(32.5 \%)$ \\
\hline 15 - 20 mms no. (\%) & $16(53.2 \%)$ & $16(40 \%)$ \\
\hline$>20 \mathrm{mms}$ no. (\%) & $5(16.67 \%)$ & $11(27.5 \%)$ \\
\hline Mean tricuspid E (m/s) & $1.02 \pm 0.44$ & $1.12 \pm 0.46$ \\
\hline Mean tricuspid E/A (m/s) & $1.71 \pm 1$ & $1.81 \pm 1.16$ \\
\hline $\begin{array}{l}\text { Mean pul. flow velocity } \\
\mathrm{m} / \mathrm{s}\end{array}$ & $1.63 \pm 1.08$ & $1.57 \pm 0.64$ \\
\hline RVSP mmHg & $37 \pm 21.26$ & $40 \pm 15.6$ \\
\hline MVP with MR no. (\%) & $9(30 \%)$ & $12(30 \%)$ \\
\hline TAM (mean) & $2 \pm 0.82$ & $2.34 \pm 1.14$ \\
\hline Mitral E (m/s) & $0.88 \pm 0.26$ & $0.83 \pm 0.30$ \\
\hline Mitral E/A (m/s) & $1.9 \pm 1.14$ & $1.67 \pm 1.16$ \\
\hline \multicolumn{3}{|c|}{ Table 2. Baseline Echocardiographic Data } \\
\hline
\end{tabular}

\section{Hospital Course}

The in-hospital course was uneventful for all patients. There was no mortality in the study population.

\section{Post-Operative Evaluation}

All patients were evaluated with detailed echocardiographic study at the time of discharge and at a follow-up visit at 3 months. The pre-operative and follow-up radiological characteristics of both groups are shown in Table 3 and Table 4.

\begin{tabular}{|c|c|c|c|}
\hline & Pre-0perative & Followup & P value \\
\hline $\begin{array}{l}\text { Radiological } \\
\text { Findings }\end{array}$ & & & \\
\hline CT Ratio & $53.8 \pm 8.42$ & $52 \pm 8.2$ & $>0.05(\mathrm{NS})$ \\
\hline $\begin{array}{c}\text { Mean MPA } \\
\text { Diameter }(\mathrm{cms})\end{array}$ & $3.8 \pm 1.16$ & $3.34 \pm 1.34$ & $>0.05$ (NS) \\
\hline $\begin{array}{c}\text { Mean RPA } \\
\text { Diameter }(\mathrm{cms})\end{array}$ & $1.3 \pm 0.64$ & $1.13 \pm 0.42$ & $>0.05(\mathrm{NS})$ \\
\hline
\end{tabular}

Table 3. Pre-Operative and Followup Radiological Characteristics < 12 yrs. Group

\begin{tabular}{|c|c|c|c|}
\hline & Pre-0perative & Followup & P Value \\
\hline $\begin{array}{c}\text { Radiological } \\
\text { Findings }\end{array}$ & $57 \pm 10.4$ & $52 \pm 9.4$ & $>0.05(\mathrm{NS})$ \\
\hline CT Ratio & $4.5 \pm 1.2$ & $3.89 \pm 1.14$ & $>0.05(\mathrm{NS})$ \\
\hline $\begin{array}{c}\text { Mean MPA } \\
\text { Diameter (cms) }\end{array}$ & $1.83 \pm 1.12$ & $1.5 \pm 0.74$ & $>0.05(\mathrm{NS})$ \\
\hline $\begin{array}{c}\text { Mean RPA } \\
\text { Diameter (cms) }\end{array}$ & $\begin{array}{r}\text { Table 4. Pre-Operative and Followup } \\
\text { Radiological Characteristics > 12 yrs. Group }\end{array}$ \\
\hline
\end{tabular}




\section{Echocardiographic Findings}

The echocardiographic findings at discharge and at 3 months followup visit in both groups are shown in Table 5 and Table 6.

\begin{tabular}{|c|c|c|c|c|c|}
\hline $\begin{aligned} & \text { Echo } \\
< & 12 \text { yrs. }\end{aligned}$ & $\begin{array}{c}\text { Pre- } \\
\text { Operative } \\
\text { Echo I }\end{array}$ & $\begin{array}{c}\text { Dis- } \\
\text { charge } \\
\text { Echo II }\end{array}$ & $\begin{array}{c}\text { Followup } \\
\text { Echo III }\end{array}$ & $\begin{array}{c}\text { P value } \\
\text { Echo I } \\
\text { vs II }\end{array}$ & $\begin{array}{c}\text { P value } \\
\text { Echo I } \\
\text { vs III }\end{array}$ \\
\hline $\begin{array}{l}\text { LVIDd } \\
\mathrm{cms}\end{array}$ & $\begin{array}{c}2.93 \pm \\
0.82\end{array}$ & $\begin{array}{c}3.36 \pm \\
0.84\end{array}$ & $\begin{array}{c}3.38 \pm \\
0.8\end{array}$ & $<0.01$ & $<0.01$ \\
\hline $\begin{array}{l}\text { RVIDd } \\
\mathrm{cms}\end{array}$ & $\begin{array}{c}3.81 \pm \\
0.86\end{array}$ & $\begin{array}{c}3.08 \pm \\
1.2\end{array}$ & $\begin{array}{c}2.9 \pm \\
0.9\end{array}$ & $<0.01$ & $<0.01$ \\
\hline $\begin{array}{c}\mathrm{LA} \\
\mathrm{cms}\end{array}$ & $\begin{array}{c}2.28 \pm \\
0.52 \\
\end{array}$ & $\begin{array}{c}2.56 \pm \\
0.66 \\
\end{array}$ & $\begin{array}{c}2.54 \pm \\
0.6\end{array}$ & $<0.01$ & $<0.01$ \\
\hline $\begin{array}{l}\text { TAM } \\
\mathrm{cms}\end{array}$ & $\begin{array}{c}2 \pm \\
0.56\end{array}$ & $\begin{array}{c}0.97 \pm \\
0.44\end{array}$ & $\begin{array}{c}0.91 \pm \\
0.44\end{array}$ & $<0.01$ & $<0.01$ \\
\hline $\begin{array}{c}\text { IVS } \\
\text { excursion }\end{array}$ & $\begin{array}{l}4.2 \pm \\
3.8\end{array}$ & 0 & 0 & $<0.01$ & $<0.01$ \\
\hline $\begin{array}{l}\text { RVSP } \\
\mathrm{mmHg}\end{array}$ & $\begin{array}{l}37 \pm \\
21.6\end{array}$ & $\begin{array}{l}28 \pm \\
10.4\end{array}$ & $\begin{array}{c}27 \pm \\
6.3\end{array}$ & $<0.01$ & $<0.01$ \\
\hline $\begin{array}{c}\text { Pul. flow } \\
\text { velocity } \\
\text { m/s }\end{array}$ & $\begin{array}{c}1.6 \pm \\
1\end{array}$ & $\begin{array}{c}1.09 \pm \\
0.48\end{array}$ & $\begin{array}{c}0.98 \pm \\
0.26\end{array}$ & $<0.01$ & $<0.01$ \\
\hline $\begin{array}{c}\text { Mitral E } \\
\mathrm{m} / \mathrm{s}\end{array}$ & $\begin{array}{c}0.88 \pm \\
0.26\end{array}$ & $\begin{array}{c}0.98 \pm \\
0.32\end{array}$ & $\begin{array}{c}1.08 \pm \\
0.3\end{array}$ & $<0.01$ & $<0.01$ \\
\hline Mitral E/A & $\begin{array}{l}1.9 \pm \\
1.14\end{array}$ & $\begin{array}{c}1.78 \pm \\
0.68\end{array}$ & $\begin{array}{c}1.68 \pm \\
0.42\end{array}$ & NS & $\begin{array}{c}>0.05 \\
(\mathrm{NS})\end{array}$ \\
\hline $\begin{array}{c}\text { Tricuspid } \\
\text { E m/s }\end{array}$ & $\begin{array}{c}1.02 \pm \\
0.44 \\
\end{array}$ & $\begin{array}{c}0.75 \pm \\
0.28 \\
\end{array}$ & $\begin{array}{c}0.68 \pm \\
0.24 \\
\end{array}$ & $<0.01$ & $<0.01$ \\
\hline $\begin{array}{c}\text { Tricuspid } \\
\text { E/A }\end{array}$ & $\begin{array}{c}1.71 \pm \\
1\end{array}$ & $\begin{array}{c}1.52 \pm \\
1.2\end{array}$ & $\begin{array}{c}1.42 \pm \\
0.8\end{array}$ & $<0.01$ & $<0.01$ \\
\hline
\end{tabular}

\begin{tabular}{|c|c|c|c|c|c|}
\hline $\begin{array}{c}\text { Echo }>12 \\
\text { Yrs. }\end{array}$ & \begin{tabular}{|c|} 
Pre- \\
operative \\
Echo I
\end{tabular} & $\begin{array}{c}\text { Dis- } \\
\text { charge } \\
\text { Echo II }\end{array}$ & $\begin{array}{c}\text { Followup } \\
\text { Echo III }\end{array}$ & $\begin{array}{c}\text { P value } \\
\text { Echo I } \\
\text { vs II }\end{array}$ & $\begin{array}{c}\text { P value } \\
\text { Echo I } \\
\text { vs III }\end{array}$ \\
\hline $\begin{array}{l}\text { LVIDd } \\
\mathrm{cms}\end{array}$ & $\begin{array}{c}3.48 \pm \\
1.06\end{array}$ & $\begin{array}{c}4.02 \pm \\
0.96\end{array}$ & $\begin{array}{l}4.0 \pm \\
70.8\end{array}$ & $<0.01$ & $<0.01$ \\
\hline $\begin{array}{c}\text { RVIDd } \\
\mathrm{cms}\end{array}$ & $\begin{array}{l}4.5 \pm \\
1.68\end{array}$ & $\begin{array}{c}3.84 \pm \\
1.04\end{array}$ & $\begin{array}{c}3.49 \pm \\
1.36\end{array}$ & $<0.01$ & $<0.01$ \\
\hline $\begin{array}{c}\mathrm{LA} \\
\mathrm{cms}\end{array}$ & $\begin{array}{c}2.9 \pm \\
0.8\end{array}$ & $\begin{array}{c}3.23 \pm \\
0.78\end{array}$ & $\begin{array}{c}3.28 \pm \\
0.46\end{array}$ & $<0.01$ & $<0.01$ \\
\hline TAM cms & $\begin{array}{l}2.3 \pm \\
1.14\end{array}$ & $\begin{array}{c}1.12 \pm \\
0.88\end{array}$ & $\begin{array}{c}1.12 \pm \\
0.54\end{array}$ & $<0.01$ & $<0.01$ \\
\hline $\begin{array}{c}\text { IVS } \\
\text { excursion }\end{array}$ & $\begin{array}{c}4 \pm \\
0.02\end{array}$ & 0 & 0 & $<0.01$ & $<0.01$ \\
\hline $\begin{array}{c}\text { RVSP } \\
\mathrm{mmHg}\end{array}$ & $\begin{array}{l}41 \pm \\
15.5\end{array}$ & $\begin{array}{c}31 \pm \\
11\end{array}$ & $\begin{array}{c}29.1 \pm \\
1.08\end{array}$ & $<0.01$ & $<0.01$ \\
\hline $\begin{array}{c}\text { Pul. flow } \\
\text { velocity } \mathrm{m} / \mathrm{s}\end{array}$ & $\begin{array}{c}1.57 \pm \\
0.64\end{array}$ & $\begin{array}{c}1.07 \pm \\
0.64\end{array}$ & $\begin{array}{c}1 \pm \\
0.54\end{array}$ & $<0.01$ & $<0.01$ \\
\hline $\begin{array}{l}\text { Mitral } \\
\mathrm{E} \mathrm{m} / \mathrm{s}\end{array}$ & $\begin{array}{c}0.83 \pm \\
0.30\end{array}$ & $\begin{array}{c}0.94 \pm \\
0.38\end{array}$ & $\begin{array}{c}0.96 \pm \\
0.38\end{array}$ & $<0.01$ & $<0.01$ \\
\hline $\begin{array}{c}\text { Mitral } \\
\text { E/A }\end{array}$ & $\begin{array}{c}1.67 \pm \\
1.16\end{array}$ & $\begin{array}{c}1.73 \pm \\
1.04\end{array}$ & $\begin{array}{c}1.66 \pm \\
1.06\end{array}$ & $\begin{array}{c}>0.05 \\
\text { (NS) }\end{array}$ & $<0.01$ \\
\hline $\begin{array}{c}\text { Tricuspid } \\
\text { E m/s }\end{array}$ & $\begin{array}{c}1.12 \pm \\
0.46\end{array}$ & $\begin{array}{c}0.75 \pm \\
0.32\end{array}$ & $\begin{array}{c}0.71 \pm \\
0.24\end{array}$ & $<0.01$ & $<0.01$ \\
\hline $\begin{array}{c}\text { Tricuspid } \\
\text { E/A }\end{array}$ & $\begin{array}{c}1.81 \pm \\
1.16\end{array}$ & $\begin{array}{c}1.61 \pm \\
0.16\end{array}$ & $\begin{array}{c}1.55 \pm \\
0.78\end{array}$ & NS & $<0.05$ \\
\hline
\end{tabular}

\section{DISCUSSION}

The study was aimed at demonstrating the short-term ventricular remodelling changes after surgical closure of ASD. The patient's population was divided into two groups. Group I comprised of patients with $\leq 12$ yrs. of age and Group II those with $>12$ yrs. of age.

The pre-operative evaluation showed that all patients in Group I were asymptomatic (NYHA Class I), while $17.5 \%$ of those in Group II were symptomatic (NYHA Class II). The predominant symptoms were dyspnoea (average duration of $7 \pm 2.3$ yrs.) and palpitation (20\%).

Radiologically, mean CT ratio was increased in Group II compared to that of Group I. Similarly, patients in Group II had increased MPA dimensions.

Pre-operative echocardiographic evaluation showed that there was enlargement of Right Ventricle (RV) compared to Left Ventricle (LV) in both age groups. The interventricular septum was paradoxical in $77 \%$ of patients of Group I and $87 \%$ in Group II and flat in $23 \%$ and 12.5 respectively.

\section{RVID}

Most of the patients in the study population had elevated preoperative RV dimensions. In Group I, the RVID decreased from $3.78 \pm 0.86 \mathrm{cms}$ to $3.13 \pm 1.2 \mathrm{cms}(17.2 \%$ reduction) at discharge and to $2.94 \pm 0.8 \mathrm{cms}$ at 3 months followup. (23.28\% reduction). Similarly, in Group II, the RVID decreased from $4.52 \pm 1.68$ to $3.83 \pm 1.01 \mathrm{cms}(15.04 \%$ reduction) at followup.

Liberthson et al noticed that the size of RV in ASD was increased compared to that of LV. ${ }^{8}$ During post-operative period of ASD closure, the RV size decreased dramatically and $\mathrm{RV}$ wall motion became normal.

\section{Tricuspid Annular Motion}

Another striking change is noticed in association with Tricuspid Annular Motion (TAM). In Group I, there was a $51.5 \%$ reduction (from $2.32 \pm 1.14 \mathrm{cms}$ to $1.11 \pm 0.88 \mathrm{cms}$ at discharge and $54.5 \%$ reduction), (from $2.32 \pm 1.14 \mathrm{cms}$ to $1.12 \pm 0.54, \mathrm{P}<0.01$ ) at followup. In Group II, this reduction was $52.14 \%$ (from $2.32 \pm 1.14$ to $1.11 \pm 0.8$ ) and $52.14 \%$ (from $2.32 \pm 1.14$ to $1.12 \pm 0.54$ ) respectively. Liberthson et al noticed that there was increased RV wall motion in cases of ASD, which became normal in the post-operative period.

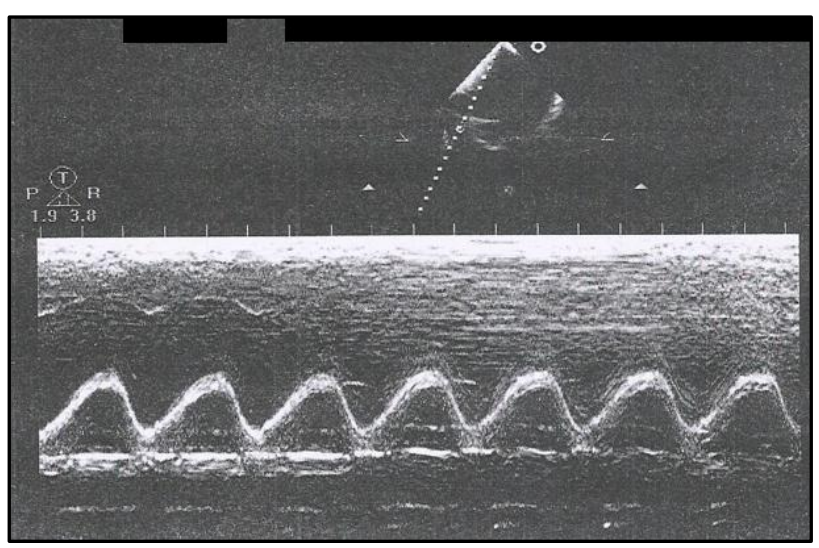

Figure 1. M-Mode Echocardiographic Picture in a Patient with Atrial Septal Defect showing Tricuspid Annular Motion (Pre-Operative Recording) 


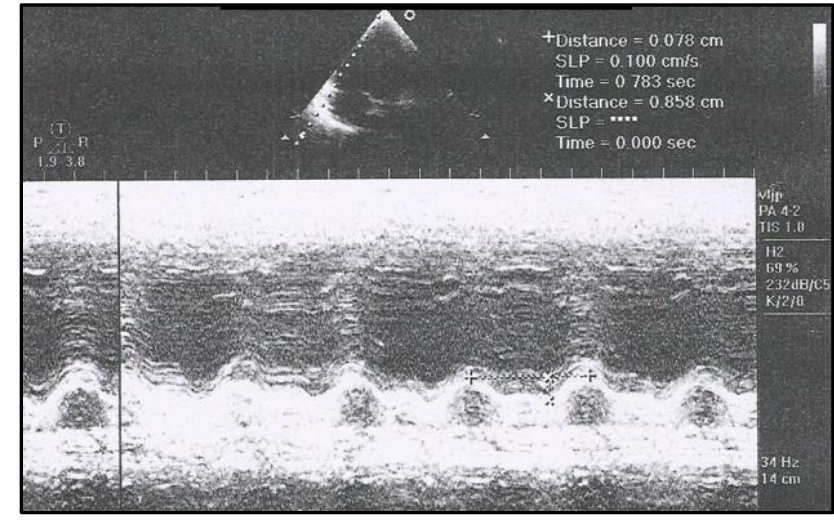

Figure 2. M-Mode Echocardiographic Picture in a Patient with Atrial Septal Defect showing Tricuspid Annular Motion (Post-Operative Recording)

\section{IVS Excursion}

The mean IVS excursion was $4.31 \mathrm{~mm}$ in Group I and $4.0 \mathrm{~mm}$ in Group II preoperatively. The IVS almost became flat at the time of discharge and followup.

\section{RVSP}

There was a significant reduction in RVSP in both groups; $24.32 \%$ at discharge and $27.02 \%$ at followup ( $\mathrm{P}<0.01)$ in Group I and $24.39 \%$ at discharge and $29.27 \%$ at followup in Group II $(\mathrm{P}<0.01)$.

Salchian et al reported a $23 \%$ reduction in RVSP (from $40.36 \pm 6.2 \mathrm{mmHg}$ to $31.0 \pm 5.3 \mathrm{mmHg}, \mathrm{P}<0.0001$ ) after ASD closure. ${ }^{9}$

\section{Doppler Flow Velocities \\ Tricuspid E Flow Velocity}

Another significant reduction was noticed in tricuspid E flow velocity. It showed a decrease of $26.4 \%$ at discharge and $33.3 \%$ at followup in Group I ( $\mathrm{P}<0.01)$. The corresponding reduction in Group II was 33\% and 33.6\% respectively ( $\mathrm{P}<$ 0.01 ). The pulmonary flow velocity also showed statistically significant reduction at discharge and followup in both the groups.

\section{LVIDd}

There was a significant increase in LVIDd in both the groups after ASD closure.

\section{LA Size}

The mean LA size showed an increase. Among patients in Group I, there was $12 \%$ increase at discharge and $13.1 \%$ at followup. The corresponding change in Group II was an increase of $11.38 \%$ and $13.1 \%$, respectively.

\section{Transmitral Flow Velocity}

There was $11.4 \%$ increase in transmitral E flow velocity at discharge and $22.7 \%$ at followup in Group I. The corresponding changes in Group II was $13.25 \%$ and $15.66 \%$, respectively.

\section{CONCLUSION}

1. Surgical closure of ASD resulted in symptomatic improvement among paediatric and adult patients during a short-term followup.

2. There was radiological evidence of reduction in cardiac size and major pulmonary vascular dimensions after surgery.

3. Echocardiographic evaluation at discharge and at 3 months revealed significant reduction in diastolic dimensions of right ventricle.

4. The diastolic left ventricular and left atrial size increased among paediatric and adult patients at the time of discharge and followup echocardiographic evaluation.

5. There was significant reduction in transtricuspid (tricuspid E), transpulmonary flow velocities and right ventricular systolic pressure after ASD closure.

6. There was significant increase in transmitral (mitral E) flow velocity.

7. The tricuspid annular motion showed significant reduction in both groups following ASD closure, probably due to reduction in right ventricular volume overload.

\section{REFERENCES}

[1] Perloff JK. The clinical recognition of congenital heart disease. $5^{\text {th }}$ edn. Saunders 2002:233-63.

[2] Webb GD. Congenital heart disease in Braunwald's Heart disease. $7^{\text {th }}$ edn. Elsevier Saunders 2005:1489547.

[3] Saxena A, Divekar A, Soni NR, et al. Natural history of secundum ASD revisited in the era of transcatheter closure. Indian Heart Jounal 2005:57(1):35-8.

[4] Sutton JMG, Tajik AJ, McGoon DC, et al. Atrial septal defect in patients aged 60 years or older: operative results and long term post-operative follow up. Circulation 1981;64(2):402-9.

[5] Murphy JG, Gersh BJ, McGoon MD, et al. Long-term outcome after surgical repair of isolated atrial septal defect. Follow-up at 27 to 32 years. N Engl J Med 1990;323(24):1645-50.

[6] Sondergard T, Paulsen PK. Some immediate hemodynamic consequences of closure of atrial septal defects of the secondum type. Circulation 1984;69(5):905-13.

[7] Roos-Hesselink JW, Meijboom FJ, Spitaels SE, et al. Excellent survival and low incidence of arrhythmias, stroke and heart failure long term after surgical ASD closure at young age. A prospective follow-up study of 21-33 years. Eur Heart J 2003;24(2):190-7.

[8] Liberthson RR, Boucher CA, Strauss HW, et al. Right ventricular function in adult atrial septal defect. Preoperative and postoperative assessment and clinical implications. Am J Cardiol 1981:47(1):56-60.

[9] Salehian 0, Horlick E, Schwerzmann M, et al. Improvements in cardiac form and function after transcatheter closure of secondum ASDs. J Am Coll Cardiol 2005;45(4):499-504. 